\title{
KONTRIBUSI EVALUASI UNTUK EFISIENSI PENGELOLAAN PROGRAM DAN KEBIJAKAN PENDIDIKAN
}

\section{Abstrak}

\author{
Oleh: \\ - Suranto AW \\ FISE UNY
}

Evaluasi adalah proses untuk menentukan seberapa jauh efisiensi pengelolaan program dan kebijakan pendidikan telah tercapai. Hal ini mengandung maksud bahwa dengan evaluasi, para pengambil kebijakan memperoleh informasi akurat sejauhmana efisiensi tersebut telah tercapai.

Dengan informasi tersebut maka program pendidikan itu dapat ditinjau kembali untuk menyusun langkah-langkah dan kegiatan-kegiatan yang lebih efisien. Dengan demikian dapat dikatakan bahwa evaluasi akan menghasilkan sejumlah informasi, dan berdasarkan informasi itu dapat dilakukan pengambilan keputusan secara komprehensif.

Kontribusi evaluasi ialah sumbangsih evaluasi melalui temuantemuan dan rekomendasinya untuk perbaikan program dan kebijakan pendidikan.

Kata kunci: Kontribusi, Evaluasi, Efisiensi.

\section{Pendahuluan}

Pada era global ini, teknologi komunikasi telah mempersatukan dunia, sehingga interaksi antarbangsapun menjadi lebih mudah. Konsekuensinya adalah bahwa persaingan global tidak terhindarkan. Dalam bidang pendidikan, persainganpun terjadi. Apabila kualitas penyelenggaraan program pendidikan tidak ditingkatkan, maka akan terjadi penurunan kepercayaan masyarakat. Hal ini menyebabkan semua negara berkompetisi untuk meningkatkan kualitas pendidikannya, karena peningkatan kualitas pendidikan merupakan salah sa- tu upaya nyata peningkatan kualitas sumber daya manusia.

Melaiui pendidikan yang efisien akan menghasilkan sumber daya manusia yang lebih berkualitas yang mampu mengelola sumber daya alam secara efektif dan efisien. Dengan memiliki sumber daya manusia yang berkualitas, produtivitas negara akan meningkat, dan pada akhirnya diharapkan akan mampu meningkatkan daya saing dan kesejahteraan masyarakat.

Efisiensi pengelolaan pendidikan dipengaruhi banyak faktor, 
antara lain: siswa, pengelola sekolah (kepala sekolah, karyawan dan komite sekolah), lingkungan (orangtua, masyarakat, sekolah), kualitas pembelajaran, kurikulum, dan sistem evaluasi (Edy Suhartoyo. 2005: 2). Hal senada juga disampaikan oleh Djemari Mardapi (2003 a: 8) bahwa usaha peningkatan kualitas dan efisiensi pengelolaan pendidikan dapat ditempuh melalui peningkatan kualitas pembelajaran dan kualitas sistem penilaian. Berdasarkan dua pendapat tersebut, tanpa mengurangi arti penting serta tanpa mengesampingkan faktor-faktor yang lain, faktor sistem evaluasi merupakan faktor yang sangat berperan dalam meningkatkan efisiensi pengelolaan pendidikan, dan oleh karena itu kinerja dari berbagai program dan kebijakan pendidikan perlu dievaluasi secara sistematis dan objektif. Dalam konteks seperti inilah maka tulisan ini disusun dengan harapan dapat memberikan wacana yang mampu meningkatkan kesadaran para pengambil kebijakan maupun praktisi pendidikan untuk melakukan evaluasi, dan menggunakan temuan evaluasi itu sebagai bahan pertimbangan pengambilan keputusan, khususnya sebagai bahan pertimbangan untuk peningkatan efisiensi pengelolaan program dan kebijakan pendidikan .

Masalahnya adalah evaluasi untuk mengetahui tingkat keberhasilan penyelenggaraan program dan kebijakan pendidikan tersebut, dewasa ini belum dilaksanakan secara memadai. Masih sering kita jumpai, program pendidikan yang sudah berjalan bahkan sudah selesai dilaksanakan belum juga dievaluasi. Adapula proses evaluasi hanya dilaksanakan secara formalitas untuk memenuhi ketentuan teknis semata. Oleh karena itu untuk lebih mengoptimalkan kinerja program pendidikan, evaluasi tersebut perlu dilakukan secara lebih komprehensif. Istilah komprehensif dalam hal ini mengandung makna bahwa cakupan evaluasi tidak hanya pada aspek output program dan kebijakan pendidikan semata, tetapi juga menjangkau seluruh komponen atau seluruh stakeholder yang berkaitan dengan proses penyelenggaraan program dan kebijakan pendidikan.

\section{Arti Penting Evaluasi}

Evaluasi merupakan salah satu rangkaian kegiatan dalam meningkatkan efisiensi, kualitas, kiner$\mathrm{ja}$, atau produktivitas suatu lembaga dalam melaksanakan programnya. Melalui evaluasi akan diperoleh informasi tentang apa yang telah dicapai dan mana yang belum tercapai, dan selanjutnya informasi ini digunakan untuk perbaikan suatu program. Menurut Tyler (1950) evaluasi adalah proses penentuan sejauhmana tujuan pendidikan telah tercapai. Banyak sekali definisi evaluasi, namun demikian dari ba- 
nyak definisi tersebut dapat dikatakan bahwa semua selalu memuat masalah informasi dan kebijakan, yaitu informasi tentang pelaksanaan dan keberhasilan suatu program yang selanjutnya digunakan untuk menentukan kebijakan berikutnya.

Arti penting pelaksanaan kegiatan evaluasi adalah untuk melihat kembali apakah suatu program dan kebijakan pendidikan itu telah dapat dilaksanakan secara efisien sesuai dengan perencanaan dan mencapai hasil sesuai yang diharapan. Dari hasil kegiatan evaluasi akan dapat diketahui hal-hal yang telah dicapai, apakah suatu program dapat memenuhi kriteria yang telah ditentukan. Berdasarkan hasil evaluasi kemudian diambil keputusan apakah program dan kebijakan tersebut akan: (1) diteruskan, (2) direvisi, (3) dihentikan, atau (4) dirumuśkan kembali sehingga dapat ditemukan tujuan, sasaran dan alternatif baru yang sama sekali berbeda dengan sebelumnya.

Dengan demikian untuk dapat melakukan pembaharuan program dan kebijakan pendidikan, kegiatan evaluasi terhadap program yang sedang maupun telah berjalan sebelumnya perlu dilakukan dengan baik. Untuk dapat menyusun program yang lebih baik, maka hasil evaluasi program sebelumnya merupakan acuan yang tidak dapat ditinggalkan.

Worthen dan Sanders (1973: 19) menyatakan bahwa: Evaluation is the determination of the worth of thing. It includes obtaining information for use in judging the worth of a program, product, procedure, or objective, or the potential utility of alternative approaches designed to attain specified objectives.

Berdasarkan pendapat di atas, evaluasi diartikan sebagai penentuan nilai (worth) terhadap sesuatu hal, yang meliputi pengumpulan informasi yang digunakan untuk menentukan nilai keberhasilan suatu program, produk, prosedur, tujuan atau manfaat potensi pada desain alternatif pendekatan, untuk mempertahankan pendekatan yang khusus. Pendapat tersebut mengimplikasikan adanya kriteria tertentu yang digunakan untuk menentukan nilai atau harga (worth) sesuatu. Kriteria yang dimaksudkan adalah kriteria keberhasilan pelaksanaan program dan hal yang dinilai adalah dapat berupa hasil yang dicapai atau prosesnya itu sendiri.

Ada lima komponen yang saling terkait dalam melaksanakan program dan kebijakan pendidikan, yaitu evaluasi, kualitas, otonomi, akuntabilitas, dan akreditasi. Dari lima komponen yang saling terkait ini, evaluasi merupakan langkah awal dalam kegiatan untuk mencari informasi akurat guna peningkatan kualitas kinerja program pendidikan. Menurut Tyler (1950) evaluasi adalah proses untuk menentukan seberapa jauh tujuan pendidikan telah tercapai. Hal ini mengandung 
maksud bahwa dengan evaluasi, para pengambil kebijakan memperoleh informasi akurat sejauhmana tujuan pendidikan telah tercapai. Dengan informasi tersebut maka program pendidikan itu dapat ditinjau kembali untuk menyusun langkah-langkah dan kegiatan-kegiatan yang lebih baik. Sementara itu Stufflebeam (1971) mengatakan evaluasi adalah proses mencari informasi untuk pembuat keputusan. Jadi untuk membuat suatu keputusan, selalu diperlukan bahan pertimbangan yang memadai. Bahan pertimbangan tersebut dapat diperoleh dari hasil evaluasi. Dengan demikian dapat dikatakan bahwa evaluasi akan menghasilkan sejumlah informasi, dan berdasarkan informasi itu dapat dilakukan pengambilan keputusan secara komprehensif.

\section{Konsep Kontribusi Evaluasi}

Banyak ahli evaluasi memaparkan peran dari evaluasi. Meskipun dengan kalimat yang berbeda-beda, dapat ditarik suatu kesimpulan bahwa evaluasi merupakan studi yang berkontribusi secara langsung pada keputusan-keputusan program dan kebijakan pendidikan. Suatu program atau kebijakan pendidikan pada umumnya menuntut untuk dilihat lagi, karena hasil penelitian yang mendasari program dan kebijakan tersebut mungkin sudah hampir usang. Mungkin sudah terjadi berbagai pergeseran kondisi komponen-komponen yang berpengaruh terhadap program pendidikan itu.
Jadi diperlukan studi berkelanjutan untuk menilai secara akurat. Studi berkelanjutan itu adalah evaluasi. Artinya proses evaluasi perlu dilakukan untuk memperoleh informasi atau temuan obyektif. Sedangkan temuan tersebut merupakan kontribusi yang dapat diberikan oleh evaluator kepada para pengambil kebijakan pendidikan.

Evaluasi program pendidikan merupakan evaluasi yang menilai aktivitas di bidang pendidikan dengan menyediakan data yang berkelanjutan. Dengan demikian evaluasi program merupakan rangkaian kegiatan yang dilakukan dengan sengaja dan secara cermat untuk mengetahui tingkat efisiensi, keterlaksanaan atau keberhasilan suatu program dengan cara mengetahi efektivitas masing-masing komponennya, baik terhadap program yang sedang berjalan maupun program yang telah berlalu.

Evaluasi berkontribusi untuk kepentingan pengambilan keputusan dalam rangka menentukan kebijakan selanjutnya. Melalui evaluasi, suatu program dan kebijakan pendidikan dapat dilakukan penilaian secara sistematik, rinci dan menggunakan prosedur yang sudah diuji secara cermat. Dengan metode tertentu akan diperoleh data yang handal, dapat dipercaya sehingga penentuan kebijakan akan tepat, dengan catatan data yang digunakan sebagai dasar pertim- 
bangan tersebut adalah data yang tepat, baik dari segi isi, cakupan, format maupun tepat dari segi waktu penyampaian.

Stuflebeam (Worthen dan Sanders, 1973: 129) memberikan penegasan kontribusi evaluasi sebagai berikut.

Evaluation is the process of delieneting, obtaining, and providing useful information for judging decision alternatives. Process, aparticular, continuing, and cyclical activity. Delineating, focusing informations requirement to be served evaluation through such step as specifying, defining, and explicating. Obtaining, making available through such formal means as statistics and measurement. Providing, fitting together into systemor subsystems that best served the needs or purposes of the evaluation.

Dari definiși di atas, evaluasi diartikan sebagai proses yang menggambarkan, menghasilkan dan menyajikan informasi yang berguna untuk pengambilan keputusan. Jadi, evaluasi merupakan kegiatan yang dilakukan secara sistematis untuk berkontribusi membantu pengambil keputusan dalam menentukan suatu kebijakan.

Berbagai program diselenggarakan untuk mencapai tujuan tertentu. Apakah tujuan yang dicanangkan tersebut dapat tercapai atau tidak, apakah dalam pelaksanaan program tersebut terdapat kendala atau tidak, memerlukan langkah-langkah evalua- si. Posavac (1985: 11) menyatakan bahwa minimal ada enam alasan melaksanakan evaluasi terhadap program dan kebijakan pendidikan, yaitu:

There are many reason for conducting program and poticy education evaluation. Among this reason are: fulfillment of acreditation requirements accounting for fund, answering request for information, making administrative decisions, assisting staf in program development, and learning about unintened effects of program. Program evaluation can be a powerful tool for improving the effectiveness of organization.

Dengan mencermati uraian di atas, dapat ditegaskan bahwa evaluasi memang penting untuk dilaksanakan. Tanpa adanya evaluasi terhadap program dan kebijakan yang telah dilaksanakan, programprogram baru maupun penyempurnaan program yang sudah ada, akan sulit dilakukan suatu perbaikan. Demikian pula tuntutan akuntabilitas tidak dapat terpenuhi, sehingga pertanggung jawaban penggunaan dana kepada masyarakat akan sulit dilakukan. Jadi evaluasi merupakan langkah mencari informasi sejauhmana segala sumber daya telah dapat berperan sesuai rencana, dan informasi seperti ini berkontribusi untuk meningkatkan efektivitas kinerja organisasi. 
Efisiensi kinerja program dan kebijakan pendidikan adalah suatu predikat yang harus senantiasa diupayakan agar terjamin secara memadai. $\mathrm{Hal}$ ini perlu ditegaskan, mengingat penyelenggaraan pendidikan bukanlah program yang sederhana. Dampak program dan kebijakan pendidikan akan menyangkut banyak orang dan banyak aspek. Oleh karena itu program pendidikan harus dievaluasi untuk mengetahui kekurangannya, dan kekurangan tersebut dapat diperbaiki untuk waktu berikutnya.

Lukman (1997: 10) mendefinisikan evaluasi sebagai suatu kegiatan menilai dan mempertimbangkan keadaan atau kualitas suatu program sebagai sumber informasi yang diperlukan untuk keperluan pembuatan keputusan. Sementara itu, Suharsimi Arikunto (1988: 2) mengatakan bahwa evaluasi program adalah suatu rangkaian kegiatan yang dilakukan dengan sengaja untuk melihat tingkat keberhasilan program. Oleh karena itu melakukan evaluasi program berarti melakukan kegiatan yang dimaksudkan untuk mengetahui seberapa tinggi tingkat keberhasilan suatu program yang direncanakan.

Secara konseptual kontribusi evaluasi ialah sumbangsih evaluasi melalui temuan-temuan dan rekomendasinya untuk perbaikan program dan kebijakan pendidikan. Dalam hal ini, level kontribusi dapat dibedakan menjadi dua, yakni: " use/penggunaan" dan "impact/dampak". Level pertama yaitu "use" berarti evaluasi itu telah memberikan kontribusi karena temuannya digunakan sebagai pertimbangan yang serius dalam proses pengambilan keputusan. Level kedua, "impact" atau dampak, berarti temuan dan rekomendasi evaluasi itu tidak saja dipakai sebagai bahan pertimbangan pengambilan keputusan, malainkan telah dilaksanakan secara empiris dalam praktik pendidikan, sehingga telah terjadi perubahan-perubahan aktual dalam program dan kebijakan pendidikan yang berasal dari penggunaan evaluasi itu.

Ambil contoh dalam pengambilan keputusan peraturan hukum di bidang pendidikan yang dilakukan oleh Dewan Perwakilan Rakyat (DPR). Surat Kabar Harian Kedaulatan Rakyat ( 2 November 2007, halaman 9) memberitakan bahwa DPR melakukan pengkajian rasional penyelenggaraan ujian nasional untuk sekolah dasar. Dalam pengkajian itu, digunakan berbagai data atau informasi hasil evaluasi yang telah ada sebagai dasar pengambilan keputusan. Dalam hal ini nampak jelas, evaluasi memang berkontribusi untuk kebijakan dan keputusan program pendidikan, dan untuk perubahan yang sesungguhnya. Dengan demikian evaluasi memiliki sejumlah kontribusi terhadap hukum, peraturan, manajemen, dan anggaran. Inilah alasan untuk mengatakan bahwa evaluasi - 
evaluasi dapat diperhatikan secara serius, dan dapat mempengaruhi isi keputusan. Bahkan pada kesempatan tertentu, evaluasi berkontribusi lebih besar karena dipergunakan sebagai acuan melaksanakan perubahan di lapangan sehingga dapat dikategorikan berkontribusi sebagai dampak.

Suatu realita, bahwa dewasa ini tidak semua program dan kebijakan pendidikan diputuskan dengan mendasarkan pada hasil-hasil penelitian evaluasi. Tidak dapat dipungkiri, adanya kebijakan pendidikan yang lebih banyak diputuskan dengan pertimbangan politik, kultural, ekonomi, dan sebagainya. Dengan demikian dapat dibuat suatu hirarki yang lebih rinci tidak sekedar use dan impact- bobot kontribusi evaluasi terhadap program dan kebijakan pendidikan, meliputi:

1. Evaluasi jarang dipakai dalam keputusan. Dalam kondisi ini pengambilan keputusan dilakukan dengan pertimbangan-pertimbangan tertentu seperti pertimbangan politik, kultural, pemerataan, dan sebagainya. Jadi keputusan tidak berdasarkan data lapangan yang diperoleh dari proses evaluasi.

2. Saat hal itu dipakai untuk keputusan, hal itu merupakan input atau masukan yang tidak penting dalam sebagian besar kasus. Dalam hal ini evaluasi hanya sebagai basa-basi. Dilakukan evaluasi, tetapi hasilnya tidak dimanfaatkan secara maksimal.

3. Sebagian lain, evaluasi dipakai sebagai penutup-jendela utuk mele- gitimasi keputusan-keputusan yang sudah diambil sebelumnya. Dalam kondisi ini, evaluasi dipergunakan sebagai sebuah perisai untuk melegitimasi pengambilan keputusan. Dengan demikian penggunaan evaluasi hanya sebagai "formalitas" belaka, dengan tujuan untuk melegalkan pengambilan keputusan.

4. Ketika dipakai dalam keputusan, keputusan-keputusanya biasanya tidak penting. Hal ini menunjukkan bahwa evaluasi sudah dipergunakan sebagai bahan pertimbangan pengambilan keputusan, tetapi keputusan-keputusan itu hanya menyangkut suatu program yang tidak terlalu penting.

5. Penggunaan utama dari evaluasi adalah sebagai pertimbangan utama pengambilan keputusan-keputusan penting dalam bidang pendidikan. Pada level ini evaluasi telah diberdayakan dengan baik. Temuan-temuan evaluasi menjadi pertimbangan utama dalam pengambilan keputusan.

6. Penggunaan evaluasi sebagai acuan memperbaiki keadaan. Kondisi ini merupakan level tertinggi kontribusi evaluasi terhadap efisiensi pengelolaan program dan kebijakan pendidikan, karena temuan evaluasi telah ditempatkan sebagai acuan utama dalam melakukan perbaikan dan peningkatan.

Menurut Chittenden (1991) kegiatan evaluasi cialam program 
dan kebijakan pendidikan perlu diarahkan pada empat hal, yaitu:

a. Penelusuran, yaitu kegiatan yang dilakukan untuk menelusuri apakah program pendidikan telah berlangsung sesuai dengan yang direncanakan atau tidak. Untuk kepentingan ini evaluator mengumpulkan berbagai informasi sepanjang semester atau sepanjang tahun melalui berbagai bentuk pengukuran dan pengumpulan data lainnya untuk memperoleh gambaran tentang pencapaian kemajuan penyelenggaraan program pendidikan.

b. Pengecekan, yaitu untuk memberi informasi apakah terdapat kekurangan-kekurangan selama proses penyelenggaraan program. Perlu dilakukan pengecekan antar sumber informasi. Inforrnasi dapat dikatakan baik, apabila setelah dilakukan cek silang terdapat konsistensi.

c. Pencarian, yaitu untuk mencari dan menemukan penyebab kekurangan yang muncul selama program berlangsung. Langkah ini perlu dilakukan secara hati-hati, agar evaluator memperoleh informasi yang dapat dipertanggungjawabkan mengenai berbagai faktor penyebab kekurangankekurangan selama program berlangsung.

d. Penyimpulan, yaitu untuk menyimpulkan tentang tingkat pencapaian program apakah sudah sesuai dengan rencana ataukah belum.

\section{Beberapa Model Evaluasi}

Terdapat banyak model yang dapat digunakan untuk mengevaluasi suatu program dan kebijakan pendidikan. Meskipun antara satu model dengan model lainnya saling berbeda dalam hal langkah atau prosedur evaluasi, namun pada hakikatnya memiliki maksud sama yaitu melakukan kegiatan pengumpulan data atau informasi yang berkenaan dengan objek yang dievaluasi. Tujuannya adalah menyediakan bahan pertimbangan bagi pengambil keputusan dalam rangka menentukan tindak lanjut suatu program.

Model-model evaluasi diberi sebutan atau nama tertentu: (a) ada yang diberi sebutan berdasarkan nama pakar yang menemukan dan mengembangkannya; (b) sesuai dengan sifat kerjanya; (c) sesuai dengan fokus atau penekanannya. Stephen Isaac (1986) membedakan adanya empat hal yang digunakan untuk membedakan ragam model evaluasi, yaitu: (-1) berorientasi pada tujuan program - goal oriented, (2) berorientasi pada keputusan decision oriented, (3) berorientasi pada kegiatan dan orang-orang yang menanganinya - transactional oriented, dan (4) berorientasi pada pengaruh dan dampak program research oriented.

Sementara itu Sanders (1973 : 42) menjelaskan bahwa dari beberapa model evaluasi yang ada, 
dapat dibedakan dalam tiya kelompok sesuai manfaatnya. Ketiga kelompok model tersebut ialah:

a. Yang menggunakan evaluasi sebagai strategi untuk memberikan pertimbangan. Pendekatan yantg digunakan lebih berorientasi pada pengukuran (measurement). Termasuk dalam kelompok ini adalah model-model evaluasi yang dikembangkan oleh Cronbach, Scriven, dan Stake.

b. Kelompok kedua yang didukung oleh Stufflebeam dan Alkin, menggenakan evaluasi sebagai bahan pertimbangan untuk pengambilan keputusan di kalangan manajemen (decision management).

c. Kelompok ketiga didukung oleh Tyler, Metfessel, dan Michael lebih tertuju pada pemberian pertimbangan dalam pengambilan keputusan untuk merencanakan tujuan (decision-objectives plans).

Beberapa literatur mengatakan bahwa sebenarnya yang dimaksud model-model evaluasi adalah sebuah frame work. Banyak pakar yang telah mengembangkan model evaluasi dan menggunakannya sebagai suatu strategi pendekatan evaluasi. Karena masing-masing pakar yang mengembangkan frame work tersebut memiliki kekhususan dalam sasaran, maka model-model yang dikembangkannya juga diarahkan pada sasaran evaluasi tertentu pula. Seperti disebutkan dalam Kaufman (1980: 106), "Evaluation models come in many varieties and are useful in different contexts and environments."

\section{Penutup}

Dengan mencermati uraian di atas, dapat ditegaskan bahwa evaluasi program memang penting untuk dilaksanakan. Tanpa adanya evaluasi terhadap program yang telah dilaksanakan, program-program baru maupun penyempurnaan program yang sudah ada, akan sulit dilakukan suatu perbaikan. Demikian pula tuntutan akuntabilitas tidak dapat terpenuhi, sehingga pertanggung jawaban pengunaan dana kepada masyarakat akan sulit dilakukan.

\section{Daftar Pustaka}

Djemari Mardapi. (2000). Evaluasi pendidikan. Makalah disampaikan pada Konvensi Pendidikan Nasional tanggal 19 23 September 2000 di Universitas Negeri Jakarta. (2003 a). Kurikulum 2004 dan optimalisasi sistem evaluasi pendidikañ di sekolah. Makalah disampaikan pada Seminar Nasional Kurikulum 2004 Berbasis Kompetensi, tanggal 10 Januari 2003 di Universitas Ahmad Dahlan Yogyakarta

dan penilaian pembelajaran mahasiswa. Makalah disajikan dalam Lokakarya Sistem Jaminan Mutu Proses Pem- 
belajaran, tanggal 19 Juni 2003 di Universitas Gadjah Mada Yogyakarta

Isaac, S. \& Michael, WB. (1983). Handbook in Research and Evaluation.

Kaufman, R. (1980). Evaluation without fear. New view point. New York.

Kirkpatrick, DL (1998). Evaluating training program: The four levels (edisi kedua). San Fransisco, CA: Berrett-Koehler Publishers.

Popham, WJ. (1975). Educational evaluation. Englewood Cliffs, NJ: Prentice Hall.
Suharsimi Arikunto. (1988). Evaluasi Program. Bumi Aksara. Jakarta.

Evaluasi Pendidikan. Bumi Aksara. Jakarta.

Valadez, J. \& Bamberger, $M$. (1994). Monitoring and evaluating social programs in developing countries. EDIWB Development Studies.

\section{Biodata Penulis}

Nama lengkap penulis adalah Suranto, M.Pd, M.Si menyelesaikan S2 pendidikan di Universitas Negeri Yogyakarta dan Non kependidikan di UNPAD Bandung, penulis adalah salah satu staf pengajar di Jurusan Pendidikan Administrasi FISE UNY 